Volume 21 Number 2 December 2021. P 265-285

https://doi.org/10.30603/au.v21i2.2389

\title{
"Habonaron Do Bona": Simalungun Community Values Philosophy and Inspiration for Anti-Corruption Education in Indonesia
}

\author{
${ }^{1}$ Yakobus Ndona, ${ }^{2}$ Liber Siagian, ${ }^{3}$ Pulumun Peterus Ginting \\ 12Prodi Pendidikan Pancasila dan Kewarganegaraan Universitas Negeri Medan. \\ ${ }^{3}$ Prodi Pendidikan Musik Universitas Negeri Medan
}

\begin{abstract}
The writing aims to reveal the wealth of values in the philosophy of habonaron do bona and find inspiration for anti-corruption education in Indonesia. In order to approach this problem, the research uses Max Scheler's axiological thinking as the primary reference. The study took data through interviews with Simalungun community leaders in the Seribu Dolok area, Simalungun Regency. The collected data were analyzed using philosophical hermeneutics: vertehen, translation, and interpretation. The interpretation movement uses Paul Recouer's hermeneutic circle pattern. The results of data analysis show that habonaron do bona has primary values that are structured like the structure of Max Scheler's values. Habonaron do Bona, both related to primary values and values education patterns, can be implemented for anti-corruption education in Indonesia.
\end{abstract}

Keywords: Habonaron do Bona, educational value, anti-corruption

\section{"Habonaron Do Bona": Falsafah Nilai Masyarakat Simalungun dan Inspirasi Bagi Pendidikan anti Korupsi Di Indonesia}

\begin{abstract}
Abstrak
Penulisan bertujuan untuk mengungkapkan kekayaan nilai pada falsafah habonaron do bona dan menemukan inspirasi bagi pendidikan anti korupsi di Indonesia. Guna mendekati masalah ini penelitian menggunakan pemikiran aksiologi Max Scheler sebagai acuan pokok. Penelitian mengambil data lewat wawancara dengan tokoh-toloh masyarakat Simalungun yang berdiam di wilayah Seribu Dolok, Kabupaten Simalungun. Data yang terkumpul dianalisa dengan menggunakan hermeneutika falsafati: vertehen, terjemahan dan interpretasi. Gerak interpretasi menggunakan pola lingkaran hermeneutika Paul Recouer. Hasil analisa data menunjukkan bahwa habonaron do bona memiliki nilai-nilai primer yang terstruktur menyerupai pengstrukturan nilai Max Scheler. Habonaron do Bona, baik berkaitan dengan nilai-nilai primer maupun pola pendidikan nilai dapat diimplementasikan bagi pendidikan anti korupsi di Indoensia.
\end{abstract}

Kata-kata kunci: Habonaron do Bona, pendidikan nilai, anti korupsi

Author correspondence

Email: yakobusndona@unimed.ac.id

Available online at http://journal.iaingorontalo.ac.id/index.php/au/index 


\section{A. Introduction}

Corruption has become the nation's main problem. On the one hand, corruption contradicts civil law and moral principles, including Islamic morals as written in Q.S. Al-Baqarah verse 188 prohibits eating other people's property; Q.S Ali-Imran verse 161, which prohibits betrayal in property matters; and Q.S An-Nisa 'verse 58 regarding the obligation to behave reasonably. ${ }^{1}$ On the other hand, the reality shows that corruption in Indonesia is increasing. Almost every day, the mass media report various corruption cases that drag state officials. Corruption has reached the representatives of the people mandated to oversee the government's performance and the judges appointed as representatives of God for public justice. The parliament is no longer fighting for the people's interests but is an agent for budget lobbyists. Judges are no longer a forum for getting justice but for winning cases for the solid and rich. There are no more state institutions that are free from corruption.

The phenomena of corruption show that since 20 years ago, the reform movement has not produced a new Indonesia free of corruption. Reforms have indeed brought a climate of freedom, produced many legal instruments, established anti-corruption institutions and transparency in budget management, but remain powerless in eliminating the corrupt behavior of state administrators.

This reality shows that reform requires a new approach. It must be realized that the primary source of corrupt behavior is not the system's weakness and the lack of legal instruments but the low values that rule the conscience. Low values have settled and are entrenched in the conscience of the individual. The dominance of low values causes individuals to commit crimes comfortably without feeling guilty. ${ }^{2}$ This fact confronts the corruption eradication movement in this country with two fundamental problems, namely a misguidance of conscience and a culture that loosens corrupt behavior. The conscience of most individuals has been shackled with low values, such as greed, indifference, and dishonesty. This situation is reinforced by the habit of close people tolerating dishonest behavior.

\footnotetext{
${ }^{1}$ Ade Kurniawan, "Pendidikan Anti Korupsi Dalam Perspektif Islam," Tsamratul -Fikri, 2019, p. 222

${ }^{2}$ Kees Bertens, Etika (Jakarta: Gramedia Pustaka Utama, 1993), p. 64.
} 
The problem now is how to internalize anti-corruption values in individual consciences and change society's culture that tolerates corrupt behavior. These two issues require value education. ${ }^{3}$ Many parties have studied the issue, including MW Nugraheni, 2016 regarding anti-corruption education in Indonesian language learning; E Subkhan $\cdot 2020$ on anti-corruption education in a critical pedagogical perspective; Y. Kadir, 2018 concerning anti-corruption education policies in universities; Agus Surono and Muslihati on anti-corruption cultural education. Several other authors also discussed anti-corruption education in the context of Islam, including L. Hakim (2012), A. Imelda (2017), U. Nasri (2020), Abdulloh Hadziq (2017), F Fauziyah (2015), N Faizatun • (2020). This paper explicitly raises the philosophy of the value of habonaron do bona in the Simalungun community as an inspiration for anti-corruption value education. The study is based on the basic assumption that local wisdom is the root of Pancasila values and often displays fundamental truths that inspire and strengthen the renewal movement towards a better civilization. ${ }^{4}$ The study focuses on three primary issues, (1) what the Simalungun community feels about habonaron do bona; (2) how is the value structure of habonaron do bona in Max Scheler's perspective; and (3) inspiration for anti-corruption education in Indonesia.

\section{B. Research Method}

The research uses a qualitative approach. The choice of this approach is based on the consideration that the orientation of the research is more on disclosing meaning than calculating numbers. ${ }^{5}$ As an analytical knife, this research uses the value structure in Max Scheler's axiology. ${ }^{6}$ The data were obtained through interviews with traditional leaders who inhabited the vicinity of the Bolon house, the palace of the former Purba Kingdom, Nagori Pematang Purba, for the period September-October 2015, November 2020, and July 2021. The choice of

\footnotetext{
${ }^{3}$ Ainiyah, Nur, and Nazar Husain Hadi Pranata Wibawa "Pembentukan Karakter Melalui Pendidikan Agama Islam." Al-Ulum 13, 2013, pp. 25-38

${ }^{4}$ Pradipto Bhagaskoro, Rommel Utungga Pasopati, and Syarifuddin Syarifuddin, "Pancasila Dalam Interaksi Kearifan Lokal Dan Ideologi Transnasional," Jurnal Inovasi Ilmu Sosial Dan Politik (JISoP), 2019, pp. 112-32.

${ }^{5}$ Kaelan, Metode Penelitian Kualitatif Bidang Filsafat (Yogyakarta: Paradigma, 2005), pp. 15-24.

${ }^{6}$ Scheler, Max, Formalism in Ethics and Non-Formal Ethics of Values: A New Attempt toward the Foundation of an Ethical Personalism (Northwestern: University Press, 1973).
} 
community leaders in this location was based on loyalty considerations to the local community. The philosophy of life of habonaron do bona and the customs of Simalungun have been passed down since the days of the kingdom. Interviews were also conducted with cultural experts Simalungun, ${ }^{7}$ Anjelo Purba and Eron Damanik. Data was also obtained through observations of the daily life and traditional rituals of the Pematang Purba Village community, Seribu Dolok, JuneJuly 2021. The data obtained were then analyzed using the Max Scheler value structure paradigm. The steps in the analysis use philosophical hermeneutic techniques: vertehen, translation, and interpretation. ${ }^{8}$ The translation technique is used to discuss exclusive ritual formulations, such as umpasa, discourses, and mantras, while interpretation is carried out to reveal their meaning. ${ }^{9}$ The interpretation movement uses the Dilthey hermeneutic circle pattern, where the parts explain the whole, and the whole explains the parts. This pattern places the understanding of each element, such as expressions, actions, and objects, in the light of the whole, such as history, general awareness or appreciation, cosmology, symbols, and social reality of the Simalungun community; instead, the whole is understood from its elements. The interpretation movement is also assisted by comparisons between elements and data sources, expert discussions, and literacy studies. ${ }^{10}$

\section{Results and Discussion}

\section{A Typical Experience of the Simalungun People}

The choice of habonaron do bona is based on the consideration that this philosophy has a wealth of values and influences the distinctive character of the Simalungun community. It can be seen from the distinctive character of this community group compared to other Batak sub-tribes. The nature of the

\footnotetext{
${ }^{7}$ Ndona, Yakobus, Kebenaran Yang Menyelamatkan: Gagasan Rasul Paulus Tentang Kebenaran Allah Dalam Janji (Medan: Yayasan Kita Menulis, 2021), p. 11.

${ }^{8}$ Kaelan, "Metode Penelitian Kualitatif Bidang Filsafat.", P. 171-172

9Iryna Liashenko, "Wilhelm Dilthey: Understanding the Human World," Philosophy and Cosmology, 2018, pp 163-169.

${ }^{10}$ Yakobus Ndona, "Peo Jawawawo: Simbol Persatuan Masyarakat Adat dan Inspirasi bagi Pengembangan Persatuan Bangsa," Prociding Seminar Nasional Reaktualisasi Konsep Kewarganegaraan Indonesia, Fakultas Ilmu Sosial Universitas Negeri Medan, 2019, 209-16.
} 
Simalungun people tends to be calm, friendly, self-controlled, and less ambitious, tends to give in, avoids conflict, accept the situation, and conform to the surrounding situation. ${ }^{11}$ Simalungun's distinctive character is also reflected in the rhythm of the music and dance moves that tend to be calm and graceful. ${ }^{12}$ Many figures say that this particular feature is related to the philosophy of life of habonaron do bona, which has been deeply entrenched in the lives of the Simalungun people. ${ }^{13}$

\section{Habonaron do Bona and Nanggodaha Bird}

Understanding the term habonaron do bona may have to refer to Soetarman's explanation regarding the story of the battle between the crown prince of the Nagur kingdom, Sang Ma, and the crown prince of the Samidora Kingdom who wanted to rule the Nagur kingdom. ${ }^{14}$ The term habonaron do bona refers to the story of the giant nanggordaha bird. It illustrates the will to perpetuate habonaron do bona by involving something with a divine dimension; ${ }^{15}$ Therefore, it becomes an indication of the vital position of this cultural element in the life of the Simalungun community.

The word habonaron refers to the Simalungun Dictionary, from the word bonar, trustworthy, plus the prefix ha and the suffix to become the noun habonaron, truth. The conjunction does, is, or is, and the word bona, the beginning or main; ${ }^{16}$ Therefore, habonaron do bona can be interpreted as truth is the beginning and the point. Habonaron do bona, as stated by Anjelo Purba (in an interview, September 9, 2015), is the truth as the beginning of everything because

\footnotetext{
${ }^{11}$ Dona Ponja, Yusra Dewi Siregar, and Anang Anas Azhar, "Dinamika Penyebaran Agama Islam Di Kerajaan Siantar, 1904-1913," Warisan: Journal of History and Cultural Heritage, 2020, p. 59.

12 Dian Lestari Saragih Lestari Saragih, "Makna Simbolis Gerak Tortor Dalihi dan Darboru dalam Konteks Upacara Pernikahan pada Masyarakat Simalungun di Desa Sipispis," Gesture: Jurnal Seni Tari, 2003, pp. 7-12.

${ }^{13}$ Sri Sulistyawati, Susy Deliani, and Nelvitia Purba, "Habonaron Do Bona as the Local Wisdom of the Simalungunese Community of North Sumatera in Preventing Corruption," Basa, 2019, pp. 3, DOI 10.4108/eai.20-9-2019.2296851.

${ }^{14}$ Hisarma Saragih, R Subhilhar, and Amir Purba, "Actualization of Local Wisdom in Simalungun Ethnics Daily Life," 2018, p. 227.

${ }^{15}$ Yakobus Ndona et al., "A Transcendental Symbol: Metaphysical Dimension of Peo Jawawawo-An Instrument for the Development of National Unity," Proceedings International Conference on Economics Education and Social Science, 2020, pp.314-318.

${ }^{16}$ Jatias Edison Saragih, p.30.
} 
it becomes the main or tree of life. Departing from this understanding, habonaron underlies the virtues and meaning of the life of the Sumalungun community. ${ }^{17}$

\section{Naibata as the source of Habonaron}

The association with the nanggordaha bird indicates that habonaron do bona has a metaphysical dimension. Habonaron do bona, referring to the opinion of Anjelo Purba (in an interview September 9, 2015) that comes from Naibata or God, which by the Simalungun community is the beginning of everything and has a perfect habonaron.

Naibata, who in Simalungun cosmology is in the upper nagori (upper world), is believed to be namar power (almighty), namar botoh (all-knowing), namar please (all-helper), pangarak-arak (guide), and most importantly, bona habonaron. (very accurate). Naibata, said Anjelo Purba (in an interview, October 3, 2015), thinks of the original, perfect, and absolute truth. Habonaron is the character of Naibata and underlies all of His works in creating and relating to all creatures.

The truth of Naibata, Purba said, includes three main elements, namely hasingtongan, hapintoron, and holong. Naibata has perfect hasingtonan or justice. He gives light, rain, sustenance to all beings, blesses the good, and punishes the evil. Naibata also has a hapintoron or perfect honesty. Hapintoron, by many figures, is considered the principal value of Naibata's habonaron. ${ }^{18}$ Naibata's honesty is seen in his sincerity in giving, without cunning and intrigue. Naibata is also a helper or a lover. Naibata loves all creation, and His love never ends. These three elements form the identity of Naibata. As stated by Anjelo Purba (in an interview, September 9, 2015), this belief is based on the social situation of the Simalungun community, which is often mistreated by the authorities and the rude attitude and intrigue of the newcomers. This experience brings the Simalungun people to a perfect depiction of justice, honesty, and love in the upper nagori.

\footnotetext{
17 Saragih, Subhilhar, and Purba, “Actualization of Local Wisdom in Simalungun Ethnics Daily Life,” p. 227.

18 Sulistyawati, Deliani, and Purba, "Habonaron Do Bona as the Local Wisdom of the Simalungunese Community of North Sumatera in Preventing Corruption," p.3.
} 
The Simalungun community, based on the belief in Naibata as the foundation of existence, puts the values of habonaron as the basis for the virtue of life. A life of virtue is based on honesty, justice, and love. Afterlife, as stated by Anjelo Purba (in an interview on November 7,2020 ), the spirits or simangots of good people join the upper nagori. The path to the upper nagori is adjusting life with Naibata, filled with berhabonaron. Humans, therefore, must place the habonaron as the subject of life that integrates itself with the life of the upper nagori (nagori atas).

This understanding makes the Simalungun people draw the values of habonaron Naibata as the basis for building the virtues of life. A bonar life is based on hasingtonan, hapintoron, and holong. The appreciation of these three values can be seen in the lifestyle of the Simalungun people since the royal era, in the kinship system, and in daily life.

\section{Habonaron in the Structure of Feudal Society}

The principle of habonaron as the basis for the primacy of life was evident in the days of the kingdom. Anjelo Purba (in an interview on September 9, 2015) said that during the royal era, the Simalungun people experienced habonaron in the caste structure. There were three castes in the royal era: the partuahon or caste of kings and masters; paromah or free people; and the diabolon caste or servants. Habonaron, in this order, is measured from the fulfillment of obligations according to the caste level. Habonaron of the partuahon can be seen from the love given, justice in action, and protection for the parumah and diabolon. Habonaron of the householder is to love, defend and pay tribute to the kingdom, and the habonaron of the diabolon is obedience, loyalty, and devotion to partuahon. Habonaron, in the context of feudal society, thus represents justice and righteousness in carrying out obligations.

\section{Habonaron in Simalungun's Kinship Structure}

Habonaron Naibata is also manifested in the tolu sahundulan five saodoran kinship system. The tolu sahundulan or three-furnace kinship system includes tondong (the mother giving), sanina (family relatives), and boru (female recipient). This structure, in 
line with the shift in the understanding of the tri-polar cosmology of the agricultural community towards the five-paddy community pattern, developed into five elements. ${ }^{19}$, by adding the tondong ni tondong (the mother giving the tondong), and the boru mintori child (the boru party from the boru).

The principles held in this kinship system are sanina pangalopan riah, tondong pangalopan podah, boru pangalopan gogoh; marsanina ningon pakkei, manat; martondong ningon respect, sombah, and marboru ningon elek, pandei, which means seninah as a place for deliberation, must be polite and careful; Tondong as a giver of advice must be respected, and the boru must be given attention, understanding, protection, and compassion. ${ }^{20}$. Habonaron, in this principle, is self-positioning and acting correctly according to its position in the kinship structure. Justice is the fulfillment of the rights of others which are my obligations. Boru, who does not fulfill the right of tondong, on the other hand, tondong, which does not fulfill the right of boru, has been mistreated because it is considered dishonest. The Simalungun people constantly affirm this truth, as shown in the advice of tondong to the boru in every formal event to fill life with habonaron values as a way to wholeness and harmony of life. ${ }^{21}$

\section{Habonaron do Bona in Daily Life}

Habonaron is also the principle of daily life for the Simalungun community. Simalungun people, in every social relationship, are required to maintain justice, honesty, and love. In the past, as stated by Anjelo Purba (in an interview, October $3,2015)$, every family had to display chicken feathers on the kitchen wall as a sign that the slaughtered chicken was not stolen. These values emphasize prudence, wisdom, and maturity in planning and acting.

The habonaron principle, as stated by Ariston Sipayung (in an interview on November 9, 2020), has made the Simalungun people only celebrate the death of

\footnotetext{
19 Yakobus Ndona, "Berru dalam Kekerabatan Sulang Silima: Hilir yang Mendamaikan," Prosiding Seminar Nasional Fakultas Ilmu Sosial Universitas Negeri Medan, 2019, pp. 717 - 721.

${ }^{20}$ Hisarma Saragih, Dinamika Penguatan Identitas Etnik Simalungun (Hasimalungunin) Di Balik Berdirinya Gereja Kristen Protestan Simalungun (Medan: Program Doktor Studi Pembangunan USU, 2018), p. 130-135.

${ }^{21}$ Diana Pramita Sumbayak et al., "Analisi Proses dan Nilai-nilai Hata-hata Mambere Podah dalam Perkawinan Adat Simalungun," Jurnal Pendidikan Bahasa dan Sastra Indonesia, 2019, pp. 181-188.
} 
Saur Matua. Only people who die old, have married all children, have grandchildren, are entitled to the highest death ritual, saur matua, because their lives have been meritorious, bear fruit, and bequeath life. ${ }^{22}$ B. Sipayung (in an interview, October 2, 2020) said that the obligation to realize habonaron do bona in life is often conveyed by simangot (ancestral spirits) through parsiarhon (possessed people) in emergencies (severe illness, death, and calamity); also tondong (wife-giving party) and tondong ni tondong (mother's uncle) as Naibata's representation to the newlyweds: "just like this arranged chicken, so will both of you live in order if you live in honesty, be fair and love one another"; and revealed in various umpasa: "your wealth is not your property, some of your wealth belongs to the poor"; "Just as a hen lays down her life for her chicks, so her life must be sacrificed for yours." 23

\section{Education of Habonaron Values}

As stated by A. Sihaloho (in an interview on November 7, 2020), Bonar life said it does not happen by itself. A bounty life is achieved through the practice or education of wisdom. Pitutur partuha Simalungun said that to achieve a bonar life, people must cultivate themselves through the limaruhut ni goluh, namely oppuoppu, didihil, dangsina, tutuduh, tutualang.

Education on the value of habonaron, said Sihaloho, must begin with oppuорри or marguru na bonar, which can be interpreted as learning the right way. Authentic learning means learning the ultimate truth and in someone enlightened. The ultimate truth is the truth embodied in the Naibata habonaron. Authentic learning puts the fundamental values of habonaron as the basis for selfdevelopment. In ancient times, people considered appropriate to be teachers of truth were tondong and guru huta or village teachers.

\footnotetext{
22 Elvera Chrismiseri Purba and Pulung Sumantri, "Perubahan Upacara Kematian Sayur Matua dalam Etnis Simalungun di Desa Sondi Raya," Puteri Hijau: Jurnal Pendidikan Sejarah, 2019, p. 102.

${ }^{23}$ Hadiani Fitri, "Habonaron Do Bona and Sapangambei Manoktok Hitei Symbols Interpreted as Simalungun Ethnic Identity in Regional AutonomyHabonaron Do Bona and Sapangambei Manoktok Hitei Symbols That Interpreted as Simalungun Ethnic Identity in Regional Autonomy," in International Conference on Contemporary Social and Political Affairs (IcoCSPA 2017), Atlantis Press, 2018, pp. 94-96.
} 
B. Sipayung (in an interview on October 5, 2020) said that true learning will result in didihil or maruhur na bonar (thinking right), dangsina or marhata na bonar (speaking right), tutuduh or marhorja na bonar (right work) and tutualang or marsaor na bonar (right association). Correct thinking is thinking with the principles of justice, honesty, and love. Thinking right is the same as planning well, straight, and without intrigue. To think/plan properly, one must control one's emotions. Things that are pleasant and unpleasant, happy and sad, sweet and bitter, good and bad are accepted as a fact of life. Ambition is natural, but it must always be controlled. In this framework, mental cultivation is essential.

Maruhur na bonar will produce marhata na bonar. An honest mind and heart, just actions, and a loving heart attitude will produce valid words. ${ }^{24}$ The right words are manifested in a polite, friendly, and not hurtful way of speaking. To speak correctly, one must understand the feelings of others and empathize with internal problems. Umpasa Simalungun reiterates lip service or avoids talking about completely unknown things parallel to other parjolo nadilat bibir ase marsahap or think before you say it. ${ }^{25}$

Maruhur na bonar will also produce tutuduh or marhorja na bonar, interpreted by working and acting right. To act right is to act justly, honestly, and in love. Maruhur na bonar will also produce tutualang or marsaor na bonar, which means good association, that is, one that does not harm others (moderately), is straight, without intrigue (honest), and loves one another. Only people who undergo this limaruhut ni goluh will have ahab or Simalungun personality. ${ }^{26}$

\section{Habonaron do Bona in Transition}

Habonaron do bona is a historical product because it has never experienced the final concept. The primary values of habonaron do bona are indeed sourced from habonaron Naibata, and therefore are objective and absolute. However, these values' understanding, development, and implications continue to evolve. The

\footnotetext{
${ }^{24}$ Sulistyawati, Deliani, and Purba, "Habonaron Do Bona as the Local Wisdom of the Simalungunese Community of North Sumatera in Preventing Corruption," p. 3.

${ }^{25}$ Sulistyawati, Deliani, and Purba, "Habonaron Do Bona as the Local Wisdom of the Simalungunese Community of North Sumatera in Preventing Corruption," pp.5

${ }^{26}$ Sulistyawati, Deliani, and Purba, "Habonaron Do Bona as the Local Wisdom of the Simalungunese Community of North Sumatera in Preventing Corruption," pp. 3-5
} 
term habonaron do bona has now become a symbol of the Simalungun district, is also contained in many regional songs, the names of various organizations, and even the labels of some local transportations, which make it even more resounding, but on the other hand, along with interactions with the surrounding tribes, the presence of immigrant cultures, inter-tribal marriages, as well as the current of globalization have made habonaron do bona undergo many transformations. This situation makes primary values that were previously considered absolute relative. The long history of the presence of Abrahamic religions, on the one hand, confirms the fundamental truth of habonaron do bona, but the labeling of infidels towards various traditional rituals that document the values of this philosophy has also shifted the values of habonaron do bona from the daily lives of the Simalungun people. ${ }^{27}$

The transformation of habonaron do bona, as stated by B. Sipayung (in an interview on September 11, 2021), is also due to the life principles of the Simalungun people, totik marsiatkon self, marombou bani simbuei, or meticulously adapting oneself and serving the public. This principle makes the Simalungun people adapt to the surrounding situation, even though they still maintain their fundamental values. This situation awakened the Simalungun traditional leaders of the Partuha Maujana Simalungun, 1984, to build a movement back to habonaron do bona. It illustrates the longing to preserve habonaron do bona, but the dominance of oral culture causes the documentation of this philosophy to be rarely done. ${ }^{28}$

\section{Value Structure in Max Scheler's Axiology}

Talking about values, it cannot be separated from the thoughts of Max Scheler, the founder and ethical figure of phenomenological values. In his book Formalism in Ethics and Non-formal Ethics of Values: A New Attempt Toward the Foundation of an Ethical Personalism, Scheler bases moral thought on values. ${ }^{29}$ The

\footnotetext{
${ }^{27}$ Yustinus Slamet \& Aloys Budi Purnomo Antono, Kekristenan Pada Kebudyaan Simalungun (Pematang Siantar: Kolportase GKPS, 2003), pp.13-76.

${ }^{28}$ D Kenan Purba and J D Poerba, Sejarah Simalungun (Bina Budaya Simalungun, 1995), pp.10-16.

${ }^{29}$ Roger C. Funk Manfred S. Frings, Scheler, Formalism in Ethics and Non-Formal Ethics of Values: A New Attempt toward the Foundation of an Ethical Personalism. (Evanston: Northwestern University Press, 1973).
} 
principle of the moral law, according to Scheler, is not to fulfill obligations because of obligations, as Emmanuel Kant said. Kant has indeed succeeded in building moral thought based on imperative autonomy to humanize humans and the world and respect personality. ${ }^{30}$ According to Scheler, such morality only becomes formalism or morality without content. Scheler asserted that the moral law musthave content, namely the realization of values. ${ }^{31}$

According to Scheler, value comes from the world of values whose existence is essentially independent of the bearer object. ${ }^{32}$ Scheler said that value is a priori because the understanding of value is not obtained from experience, but we get it when we are aware of it. $^{33}$ Values already exist and are present in our consciousness when our consciousness finds them. There may still be many unknown values because we are unaware of them. ${ }^{34}$

Scheler continues that value is not understood by ratio but by emotional intuition directed to the object (intentionality). According to Scheler, human intuition can perceive and feel value without relying on sensory experience. ${ }^{35}$ Scheler's thoughts, and values are realized through objects that act as value bearers: objects, people, places, and actions. Through these objects, the previously potential value becomes real in our experience. ${ }^{36} \mathrm{~A}$ value in an object often gives rise to accompanying secondary values. ${ }^{37}$

Value, in objects, becomes a secondary quality of the object. The value does not determine the existence of the object. Value is independent and not identical to the object. The value does not change even if the object changes. ${ }^{38}$ People can still capture the value without the object. This independence is more evident in the

30 Yinghua Lu, "The a Priori Value and Feeling in Max Scheler and Wang Yangming," Asian Philosophy, 2014, pp. 197-211.

${ }^{31}$ Franz Magnis-Suseno, Etika Abad Kedua Puluh (Yogyakarta: Yogyakarta, 2006), pp. 15-21.

32 Yakobus Ndona, "Kemanusiaan Dalam Falsafah Hidup Masyarakat Batak Toba," Jurnal Citizenship: Media Publikasi Pendidikan Pancasila Dan Kewarganegaraan, 2018, pp. 15-22.

33 Yinghua Lu, "The a Priori Value and Feeling in Max Scheler and Wang Yangming," Asian Philosophy, 2014, pp. 200-201.

34 Paulus Wahana, Nilai: Etika Aksiologis Max Scheler (Yogyakarta: Kanisius, 2004), pp. 36-42.

35 Jirzanah Jirzanah, "Aktualisasi Pemahaman Nilai Menurut Max Scheler bagi Masa Depan Bangsa Indonesia," Jurnal Filsafat, 2016, pp 93-114, https://doi.org/10.22146/jf.3519.

${ }^{36}$ Risieri Frondizi, What Is Value?, Trans, S. Lipp, La Salle, IL: Open Court, 1963. Pp. 128-140.

${ }^{37}$ Magnis-Suseno, Etika Abad Kedua Puluh, pp. 15-20.

38 Marista Christina Shally Kabelen, "Fenomenologi Nilai Slametan Masyarakat Yogyakarta Dalam Perspektif Max Scheler," Jurnal Desain, 2017, p. 252-253. 
higher value environment (aesthetic and ethical). Values also depend not only on reality but also on the reaction and psychological condition of the subject. Values are not relative, along with the subject's relative psychological and psychophysical conditions. Value is not a product of history because it does not change as history changes. ${ }^{39}$

Scheler groups values into two categories, namely good values and wrong values. ${ }^{40}$ Good values must exist and be realized, while negative values are values that should not exist in the reality of life. The relationship between moral obligations and values rests on the following two axioms. (1) Every obligation is based on value. Something positive must exist, and vice versa, something negative is something that must not exist. (2) The truth of positive values is positive because it must exist, while the truth of the negative value is negative in itself, so it must not exist.

Scheler groups values in a hierarchy of values divided into four levels or clusters. The first group consists of values related to good and bad, in the form of objects, functions, and circumstances that produce taste values. Along with good and bad values, there are particular groups of consecutive values, namely values that are the conclusions and consequences of primary values (good or bad), namely technical values that produce excellent and sour tastes, and symbols that describe the taste.

The second group has strong values or life. This cluster includes values around solid feelings, such as noble values, humiliation, courage, and fear. ${ }^{41}$ Strong values are independent values that cannot be returned to the groups below (good and bad values) or those above them (spiritual values).

The third group is spiritual values. This group includes aesthetic values, truth, justice, and pure understanding. The fourth group is sacred and profane values. Humans internalize these values as religious values. There are still clusters

\footnotetext{
39 Milton Thorman Pardosi and Septiana Dwiputri Maharani, "Kajian Aksiologi Max Scheler Terhadap Operasi Merubah Kelamin Pada Manusia (Transeksual)," Jurnal Filsafat Indonesia, 2019, pp.55.

${ }^{40}$ Frondizi, What Is Value? pp. 94-102.

${ }^{41}$ Magnis-Suseno, Etika Abad Kedua Puluh, pp. 21-29.
} 
of usefulness values and moral values. However, these two values do not have their content and material because at every level of value, and there are both values. ${ }^{42}$

Clusters of unpleasant taste or pleasure are at the lowest level. The fourth cluster is the highest in the value hierarchy. This hierarchy of values is a priori, not determined by experience, the object of the bearer of value, and the perceiver of value. Once we meet the same values and compete, we automatically know which value should come first. For example, when there is an encounter/competition between healthy and good values, we naturally prioritize healthy values over tasty ones. When we encounter the "right" value, we will take precedence over the value below it. The problem of people prioritizing good values over unpleasant values is also not because of the result of induction and experience. However, it comes from the nature of values and sensory feelings. ${ }^{43}$

In principle, this level of value appears in our consciousness a priori. However, as far as its presence in the object, some criteria are level in the hierarchy of values, namely the intrinsic tendency to maintain the state, the impossibility of sharing, the relative dependence on other values, the depth of satisfaction, and the degree of relativity. ${ }^{44}$

\section{Value Structure of Habonaron do Bona in Max Scheler's Perspective}

The philosophy of habonaron do bona, viewed from the perspective of Max Scheler, can be structured as follows. First, values underlie morality. Identical to Scheler, the philosophy of habonaron do bona puts values as the basis of moral obligation. For the Simalungun people, what must be done is following habonaron values, and what should not be done is contrary to them. Good deeds in all aspects of life manifest or at least conform to the values of habonaron, and bad deeds are against it. The Simalungun people aspire to build a moral and virtuous life by realizing the values of habonaron in their daily lives.

Second, objectivity and absolute value. The three fundamental values in habonaron do bona exist in Naibata and belong to Naibata. Justice, honesty, and love for the

\footnotetext{
42 Frondizi, What Is Value? pp. 94-102.

43 Frondizi, What Is Value? pp. 82-89.

${ }^{44}$ Frondizi, What Is Value? pp. 92-100.
} 
Simalungun people are Naibata's life because they are Naibata's virtues. Naibata's concept of immortality and absoluteness brings consequences for the immortality and absoluteness of His self-quality so that the values he possesses are also eternal and absolute.

The values of habonaron, because they have divine origins are objective. These values had existed before humans realized them through various objects. Humans searching for identity and struggle to overcome the fundamental problems of life find the values of habonaron Naibata as a way to liberation and perfection of life. In this stage, there is an encounter of values with human consciousness, which is stimulated by interactions with the environment and struggles with various life problems, including a long history of dealing with war and colonialism. Awareness of the value continues in the effort to subject it. At these two stages, there must be value relativity.

The third is the value hierarchy. Observing the description of values in the philosophy of habonaron do bona, a hierarchy of values appears, although they cannot be separated sharply. At the highest level are the values of habonaron, which are in Naibata absolutes. The habonaron primary values are emitted from the Naibata habonaron values at the second level. The third or lowest level is secondary values that accompany primary values in realizing objects: thoughts, views, words, behavior, manners, and valuable objects.

Fourth, spiritual values. The primary values of habonaron can be said to include spiritual values. The values of habonaron do not touch on the question of good or bad, about vitality or life, but concern the good and bad of life and human behavior. Perhaps more accurately called moral values. It is understandable because the Simalungun people's attention is not on objects and the universe but humans, even when talking about the upper nagori and Naibata. Habonaron do bona is a quality humans need to obtain virtue, harmony, and salvation.

At the realization stage in the object, the secondary values that appear can be categorized as strong values and even pleasure values. Honest people are often motivated to get blessings, health, avoid harm, and security; however, these values are still rooted in the primary values that originate from divinity and underlie the priority of life. 


\section{Critical Reflection - The Relevance of Habonaron do Bona for Anti- Corruption Education}

The values in habonaron do bona cannot be claimed as exclusively owned by the Simalungun community. Many communities, including Islam, also have a wealth of values as the basis for the virtues of life. The primary values of habonaron do bona, including the Naibata values, do almost all ethnic groups and religions share universal values. Although not the same, this value structure is also found in the ethnic groups of the archipelago. ${ }^{45}$ And even the world. ${ }^{46}$ It shows a universal awareness of values as the basis for the primacy of life and human morality.

The pattern of appreciation of habonaron do bona in the kinship system is also owned by the Pakpak community, who are still neighbors and kin. ${ }^{47}$ Truth, for the Pakpak community. ${ }^{48}$ Is determined by conformity to position in the kinship structure and social order. Javanese people also have a similar understanding. The Javanese believe that the order in society is a picture of the macrocosm, the universe created by the divine. The social order, as a macro-cosmic representation, thus has absolute truth, thus obliging individuals in society to find their position and adjust their roles to the order. ${ }^{49}$ Truth in traditional society is thus understood as a conformist or adaptive attitude to the order. It has resulted in the prohibition of contra, ambitious, provocative attitudes, and sometimes even personal initiatives because they endanger public order, disrupt harmony and damage the sacredness of the cosmos. ${ }^{50}$

\footnotetext{
45 Yakobus Ndona, Jejak Tuhan Di Tanah Keo: Pewahyuan Pada Peo Jawawawo Dan Sumbangan Bagi Penguatan Religiusitas Gereja Katolik Indonesia, 1st ed (Yogyakarta: Keppel, 2019), p. 170-183.

46 Ekaterina Kostina et al., "Universal Human Values: Cross-Cultural Comparative Analysis," Procedia-Social and Behavioral Sciences 214, 2015, pp. 1019-1028.

${ }^{47}$ Yakobus Ndona, "Berru dalam Kekerabatan Sulang Silima: Hilir yang Mendamaikan," p. 717.

48 Yakobus Ndona and Johannes Jefria Gultom, "Puang: A Medium of Blessings in Kinship System of Pakpak Tribe," in International Conference on Social Sciences and Interdisciplinary Studies (ICSSIS) 2019, DOI 10.4108/eai.24-10-2019.2290567

49 Yakobus Ndona, Revelasi Ilahi Pada Peo Jawawawo-Keo Tengah Dalam Perspektif Metafisika Simbol Karl Jaspers: Sumbangan Bagi Penguatan Religiusitas Masyarakat Katolik Indonesia (Universitas Gadjah Mada, 2019), pp. 222-224.

50 Yakobus Ndona, "Kecenderungan Sentipetal pada Masyarakat Jawawawo-Keo Tengah," Prociding Seminar Nasional Fakultas Ilmu Sosial Unimed, 2018. pp. 490-492, http://semnasfis.unimed.ac.id 2018.
} 
"Habonaron Do Bona": Simalungun Community Values Philosophy and Inspiration for Anti-Corruption Education in Indonesia

This appreciation is also clearly seen in the indigenous people of Jawawawo, Keo Tengah, Flores. The Jawawawo people identify "community" with the house, so those are positioned as pillars, crossbars, pegs, and pairs of children.51. Every element in society must place itself according to its respective positions to ensure public order. ${ }^{52}$ Any deviation is considered to disturb the order and destroy the sacred cosmos. ${ }^{53}$ Habonaron, in a traditional society that upholds social order, can always be said to see it as harmony with the social order.

However, the Simalungun community's appreciation of the values of habonaron do bona is at least a light for many people to find the values inherited in their own culture and documented in various cultural objects. The appreciation of the values of habonaron do bona also becomes a light for Muslims to find the wealth of values in sacred documents and traditional heritage. Islam itself is a religion that bases morality on virtue. Education on the values of habonaron do Bona can at least make Muslims aware of Islamic values education to build the virtues of life, including through goodness and justice (QS. An-Nahl: 90), good speech (Qs. Al-Baqarah: 83), treats well with everyone (Qs. An-nisa": 36), against pettiness" (dha "af) and narrowness of mind (qathr). All of this is part of purification (Sura Asy-Shams: 8-10) and strengthening the soul so that it does not waver or fall into arrogance (Surah 70: 19-12) and makes it more beloved to Allah (Qs. Al-Baqarah: 195). The education of nula habonaron do bona reminds Muslims of the importance of aqal and heart management, which leads to Ihsan, which Al Ghazaly calls the stage of structuring the deepest, hidden inner behavior (sarirah), namely the eyes of the heart (bashirah). ${ }^{54}$ Muslims need to familiarize themselves with muraqobah-musyahadah-ma'rifah, monitoring the inclinations of the heart, dhikr, and tafakkur to reach the essence, the stage of purification of the soul

\footnotetext{
51 Yakobus Ndona, "Peo Jawawawo: Simbol Persatuan Masyarakat Aadat dan Inspirasi bagi Pengembangan Persatuan Bangsa," Prosiding Seminar Nasional Reaktualisasi Konsep Kewarganegaraan Indonesia, 2019, p. 209-216.

52 Yakobus Ndona et al., "A Transcendental Symbol: Metaphysical Dimension of Peo Jawawawo-An Instrument for the Development of National Unity," Proceedings of the 1st Unimed International Conference on Economics Education and Social Science (UNICEES), 2018), pp. 314-318

53 Yakobus Ndona and Paulinus Tibo, "Jawawawo Natural Monisms: Revelation Dimension of Peo and Inspiration for Faith-Dialogue in Multi-Religious Society," Budapest International Research in Linguistics and Education Sciences (BirLE), 2019, 74-84.

${ }^{54}$ Armyn Hasibuan, "Signifikansi Manajemen Kalbu Dalam Memasuki Dunia Sufi," HIKMAH: Jurnal Ilmu Dakwah Dan Komunikasi Islam, 2013, pp. 34-51.
} 
towards ma'rifat, where the soul can face the veil of preamble and musyahadah or see God. All of this will build soul strength so as not to be dragged into the temptation of corruption. 55

In the context of anti-corruption education in Indonesia, the philosophy of habonaron do bona and the value of education that accompanies it provides several main inspirations. First, anti-corruption education should be more focused on restructuring values. Indonesian people, because culture and religion actually have a wealth of values, but in the course of life, they often place low values in a primary position, which makes people unable to control their freedom, lack respect for the rights of others, are not upright, do not care about the loss of others. Others do not even feel guilty when they commit a crime. ${ }^{56}$ Anti-corruption education must continue to seek inspiration and new models to restructure the values of the nation's children to re-place honesty, justice, love, and self-control as primary values and occupy the highest cluster. ${ }^{57}$

Second, placing primary values as a way of salvation. The Simalungun people believe that the embodiment of the values of habonaron do bona is the way to get blessings and the entrance to the upper nagori. This pattern of awareness can motivate the Indonesian religious community to put the embodiment of the primary values of habonaron do bona as a way of salvation and therefore requires individuals to internalize and make it happen. This awareness becomes stronger when accompanied by an appreciation of the objectivity and absoluteness of the primary values of habonaron.

Third, primary values as the main foothold in character education. The primary values in the philosophy of habonaron do bona values can help this nation find the focus of anti-corruption education. The Ministry of National Education has listed many values in character education but without a clear focus. It causes value education to only become a formality without certainty of implementation. The

\footnotetext{
${ }^{55}$ Ade Kurniawan, "Pendidikan Anti Korupsi Dalam Perspektif Islam" Tsamratul Fikri: Jurnal Studi Islam, 2019, p. 222

${ }^{56}$ Kess Bertens, Etika, p.64-65.

57 Muzayyanah Yuliasih, Nandang Najmulmunir, and Yayat Suharyat, "The Analysis of Pancasila Universal Values and Islamic Religion," Proceedings Global Multidipsilinary Research Conference (GMRC), 2019, pp. 18-22.
} 
three primary values in habonaron do bona can focus on character education and anti-corruption education.

Fourth is the value education model. Education on the value of habonaron do bona has clear stages and details in the five ruhut ni goluh. With this pattern, the Simalungun people have a clear and measurable concept of things and stages to apply and develop habonaron values. It can inspire policymakers to determine precise and proportional stages and details in anti-corruption value education. Education on the value of habonaron do bona also shows the need to develop anticorruption characters based on local culture.

\section{Conclusion}

In conclusion, it should be emphasized that the philosophy of life of habonaron do bona, although not a systematic, rational thought, has a clear concept and structure of values. The values in habonaron do bona are universal values. The specialty of habonaron do bona lies in injustice, honesty, and love as primary values that underlie the virtues of life, with binding power because it has a divine origin, the Naibata. This aspect can inspire the Indonesian religious plural community, which places God as the foundation of existence. The divine origin can oblige the nation's citizens to internalize the fundamental values of anti-corruption as a foundation for building existence.

Finally, habonaron do bona can be a light for all communities in the archipelago to discover the richness of values in culture and religion; and restructure values by placing the fundamental values of anti-corruption as the primary value and placing them at the top of the value cluster. State administrators, especially those engaged in education, must continue to look for new models that effectively restructure the values of the nation's children in order to build a more civilized and prosperous Indonesia.

\section{References}

Antono, Yustinus Slamet \& Aloys Budi Purnomo. Kekristenan Pada Kebudyaan Simalungun. Pematang Siantar: Kolportase GKPS, 2003.

Bertens, Kees. Etika. Jakarta: Gramedia Pustaka Utama, 1993. 
Bhagaskoro, Pradipto, Rommel Utungga Pasopati, and Syarifuddin Syarifuddin. "Pancasila Dalam Interaksi Kearifan Lokal Dan Ideologi Transnasional." Jurnal Inovasi Ilmu Sosial Dan Politik (JISoP) 1, no. 2 (2019): 112-32.

Fitri, Hadiani. "Habonaron Do Bona and Sapangambei Manoktok Hitei Symbols Interpreted as Simalungun Ethnic Identity in Regional AutonomyHabonaron Do Bona and Sapangambei Manoktok Hitei Symbols That Interpreted as Simalungun Ethnic Identity in Regional Autonomy." In International Conference on Contemporary Social and Political Affairs (IcoCSPA 2017), 94-96. Atlantis Press, 2018.

Frondizi, Risieri. What Is Value?, Trans. S. Lipp, La Salle, IL: Open Court, 1963.

Hasibuan, Armyn. "Signifikansi Manajemen Kalbu Dalam Memasuki Dunia Sufi." HIKMAH: Jurnal Ilmu Dakwah Dan Komunikasi Islam 7, no. 1 (2013): 34-51.

Hisarma Saragih, Subhilhar, R.Hamdani Harahap, Amir Purba. "Aktualisasi Pemahaman Nilai Menurut Max Scheler Bagi Masa Depan Bangsa Indonesia." Jurnal Filsafat 18, no. 1 (2016): 93-114. https://doi.org/10.22146/jf.3519.

Kabelen, Marista Christina Shally. "Fenomenologi Nilai Slametan Masyarakat Yogyakarta Dalam Perspektif Max Scheler." Jurnal Desain 4, no. 03 (2017): 249-64.

Kaelan, M S. “Metode Penelitian Kualitatif Bidang Filsafat.” Yogyakarta: Paradigma, 2005.

Kostina, Ekaterina, Larisa Kretova, Raisa Teleshova, Anna Tsepkova, and Timur Vezirov. "Universal Human Values: Cross-Cultural Comparative Analysis." Procedia-Social and Behavioral Sciences 214 (2015): 1019-28.

Kurniawan, Ade. "Pendidikan Anti Korupsi Dalam Perspektif Islam." Tsamratul -Fikri 13, no. 2 (2019).

KURNIAWAN, Ade. "Pendidikan Anti Korupsi Dalam Perspektif Islam.” Tsamratul Fikri/ Jurnal Studi Islam 13 (n.d.): 221-34.

Liashenko, Iryna. "Wilhelm Dilthey: Understanding the Human World." Philosophy and Cosmology 20, no. 20 (2018): 163-69.

Lu, Yinghua. "The a Priori Value and Feeling in Max Scheler and Wang Yangming." Asian Philosophy 24, no. 3 (2014): 197-211.

Magnis-Suseno, Franz. Etika Abad Kedua Puluh. Yogyakarta: Yogyakarta, 2006.

Manfred S. Frings, Roger C. Funk. Scheler, Formalism in Ethics and Non-Formal Ethics of Values: A New Attempt toward the Foundation of an Ethical Personalism. Evanston: Northwestern University Press, 1973.

Ndona, Yakobus. "BERRU DALAM KEKERABATAN SULANG SILIMA: HILIR YANG MENDAMAIKAN," 2019.

-_- Jejak Tuhan Di Tanah Keo: Pewahyuan Pada Peo Jawawawo Dan Sumbangan Bagi Penguatan Religiusitas Gereja Katolik Indonesia. 1st ed. Yogyakarta: Keppel, 2019.

- - - Kebenaran Allah Yang Menyelamatkan: Gagasan Rasul Paulus Tentang Kebenaran Allah Dalam Janji. Medan: Yayasan Kita Menulis, 2021.

- - "KECENDERUNGAN SENTIPETAL PADA MASYARAKAT JAWAWAWO-KEO TENGAH," 2018.

- - - "Kemanusiaan Dalam Falsafah Hidup Masyarakat Batak Toba." Jurnal Citizenship: Media Publikasi Pendidikan Pancasila Dan Kewarganegaraan 1, no. 1 (2018): 15-22.

- - "PEO JAWAWAWO: SIMBOL PERSATUAN MASYARAKAT ADAT DAN INSPIRASI BAGI
PENGEMBANGAN PERSATUAN BANGSA." In PROSIDING SEMINAR NASIONAL
"REAKTUALISASI KONSEP KEWARGANEGARAAN INDONESIA," 1:209-16. FAKULTAS ILMU
SOSIAL UNIVERSITAS NEGERI MEDAN, 2019.

- - - "Revelasi Ilahi Pada Peo Jawawawo-Keo Tengah Dalam Perspektif Metafisika Simbol Karl 
“Habonaron Do Bona”: Simalungun Community Values Philosophy and Inspiration for Anti-Corruption Education in Indonesia

Jaspers: Sumbangan Bagi Penguatan Religiusitas Masyarakat Katolik Indonesia." Universitas Gadjah Mada, 2019.

Ndona, Yakobus, and Johannes Jefria Gultom. "Puang: A Medium of Blessings in Kinship System of Pakpak Tribe," 2019.

Ndona, Yakobus, Johannes Jefria Gultom, Budi Ali Mukmin, and Arief Wahyudi. "A Transcendental Symbol: Metaphysical Dimension of Peo Jawawawo-An Instrument for the Development of National Unity," 2020.

Ndona, Yakobus, and Paulinus Tibo. "Jawawawo Natural Monisms: Revelation Dimension of Peo and Inspiration for Faith-Dialogue in Multi-Religious Society." Budapest International Research in Linguistics and Education Sciences (BirLE), 2019, 74-84.

Pardosi, Milton Thorman, and Septiana Dwiputri Maharani. "Kajian Aksiologi Max Scheler Terhadap Operasi Merubah Kelamin Pada Manusia (Transeksual)." Jurnal Filsafat Indonesia 2, no. 1 (2019): 52-61.

Ponja, Dona, Yusra Dewi Siregar, and Anang Anas Azhar. "Dinamika Penyebaran Agama Islam Di Kerajaan Siantar, 1904-1913." Warisan: Journal of History and Cultural Heritage 1, no. 2 (2020): 55-60.

Purba, D Kenan, and J D Poerba. Sejarah Simalungun. Bina Budaya Simalungun, 1995.

Purba, Elvera Chrismiseri, and Pulung Sumantri. "PERUBAHAN UPACARA KEMATIAN SAYUR MATUA DALAM ETNIS SIMALUNGUN DI DESA SONDI RAYA." Puteri Hijau: Jurnal Pendidikan Sejarah 5, no. 1 (2019): 101-10.

Saragih, Dian Lestari Saragih Lestari. "MAKNA SIMBOLIS GERAK TORTOR DALAHI DAN DABORU DALAM KONTEKS UPACARA PERNIKAHAN PADA MASYARAKAT SIMALUNGUN DI DESA SIPISPIS." Gesture: Jurnal Seni Tari 2, no. 1 (2003).

Saragih, Hisarma. Dinamika Penguatan Identitas Etnik Simalungun (Hasimalungunin) Di Balik Berdirinya Gereja Kristen Protestan Simalungun (Disertasi). Medan: Program Doktor Studi Pembangunan USU, 2018.

Saragih, Hisarma, R Subhilhar, and Amir Purba. "Actualization of Local Wisdom in Simalungun Ethnics Daily Life." Advances in Social Science, Education and Humanities Research, 2018.

Saragih, Jatias Edison. Kamus Simalungun Indonesia. GKPS, 1989.

Scheler, Max. Formalism in Ethics and Non-Formal Ethics of Values: A New Attempt toward the Foundation of an Ethical Personalism. Northwestern University Press, 1973.

Sulistyawati, Sri, Susy Deliani, and Nelvitia Purba. "Habonaron Do Bona as the Local Wisdom of the Simalungunese Community of North Sumatera in Preventing Corruption," 2020.

Sumbayak, Diana Pramita, Siti Fatimah Sipayung, Pahala Manik, and Ermina Waruwu. "ANALISIS PROSES DAN NILAI HATA-HATA MAMBERE PODAH DALAM PERKAWINAN ADAT SIMALUNGUN," 2019.

Wahana, Paulus. Nilai: Rtika Aksiologis Max Scheler. Yogyakarta: Kanisius, 2004.

Yuliasih, Muzayyanah, Nandang Najmulmunir, and Yayat Suharyat. "The Analysis of Pancasila Universal Values and Islamic Religion." In GLOBAL MULTIDISCIPLINARY RESEARCH CONFERENCE(GMRC 2019), 16, 2019. 